Meta

Journal des traducteurs

Translators' Journal

\title{
Translation Theory: An Appraisal of Some General Problems
}

\section{Marge E. Landsberg}

Volume 21, numéro 4, décembre 1976

URI : https://id.erudit.org/iderudit/003396ar

DOI : https://doi.org/10.7202/003396ar

Aller au sommaire du numéro

Éditeur(s)

Les Presses de l'Université de Montréal

ISSN

0026-0452 (imprimé)

1492-1421 (numérique)

Découvrir la revue

Citer cet article

Landsberg, M. E. (1976). Translation Theory: An Appraisal of Some General Problems. Meta, 21(4), 235-251. https://doi.org/10.7202/003396ar d'utilisation que vous pouvez consulter en ligne.

https://apropos.erudit.org/fr/usagers/politique-dutilisation/ 


\section{Translation Theory: An Appraisal of Some General Problems}

The aim of translation is to reproduce in the TL, as faithfully as possible (i.e. at all levels : morphological, phonological, syntactic, lexical, semantic - and even stylistic), all the linguistic features of which the SL is composed. Translation is seen in this present paper as a rigorous, linguistically based (i.e. on findings of modern linguistic theory), investigation of the translation process, leading to the construction of a translation model, which will explain how translation from $\mathrm{SL} \rightarrow \mathrm{TL}$ takes place.

Clearly, in essence and by nature, translation theory is based on a comparison of languages. However, in spite of some important and interesting developments in recent linguistic research, our actual scientific knowledge and understanding of the "great underlying principle", i.e. "theory of human language $"$ is admittedly at present less than impressive. Having as yet no satisfactory theory of (one) language, it may seem rather presumptuous to propose to undertake a comparison of the unknowns : SL and TL...

The alternative seems simple: the paper can either end here - but that would be to acknowledge defeat - or we must make shift with what we have. Evidently, I have chosen the latter, and I propose therefore in this paper to investigate some of the most pressing problems of translation theory today.

Living as we do in the age of expanding communication, exposes us just enough to other people's cultures, experiences, and symbolic systems, to leave us with insights craving infinitely more penetrating discernments. Since this requires a meticulous scrutiny both of the language structures and of the other related aspects of the cultures concerned, it is, to be sure, no mean task. For even if, for our present purposes, we are mainly interested in some selected aspects of the problems that may arise in general SL $\rightarrow$ TL situations, these will appear to be manifold and baffling enough.

The problem seems to be not so much that one language draws a greater or lesser number of semantic distinctions than another - though that clearly is what prevents the easy one-to-one matching of their vocabularies in the first place - but rather than these distinctions are so often made in completely different 
places, often leaving voids, or " holes in the map ", i.e. anisomorphism or notequal-form (Lyons : 1969).

One usually thinks of giving the meaning of a term by some sort of paraphrase or, in other words, description of the object, idea or situation referred to, by other, preferably " semantically equivalent "terms. When this kind of linguistic transaction goes on between two languages where the nonlinguistic cultures are identical or at least similar, we speak of cultural overlap, translation can take place immediately and directly, and is indeed, in general both quite exact and

unproblematic. Thus, German Schwiegermutter = mother-in-law, Hebrew hazīr $=$ pig, and French la plante de ma tante $=$ my aunt's plant.

But where cultures and experiences differ, and we are faced with the problems of sematic relativity or anisomorphism, the translator's task may very well soon appear to assume oppressive proportions.

Instances of this are by now well enough known through the pioneering fieldwork of the anthropologists. Problems may vary from disparities in kindship semantics, involving naming and address, and general role terminology ${ }^{1}$, to colour terms, and to such highly abstract concepts as for instance, the Hopi-, or Nootka Indians' concept of " duration ", which appears so startlingly to differ from our own western concepts of "time", since this seems to be simply inconceivable in terms of motion or space (Carroll, Ed. : 1956).

Perhaps it is here that different "world-views " are most irreconcilable, for our concepts of space are so pervasive that we transfer them almost totally to time, in fact treating it as if it were a physically carvable mass, to be cut up in halves and quarters like a cake.

From the translator's viewpoint, such a radical divergence of " basic " concepts is particularly problematic in science, for although general scientific terminology may be international, in more specific scientific communication, language, culture and experience (or " think") differences must effectively be overcome, if chaos is not to ensue. Indeed, what is one to do if either the SL or the TL does not lend itself at all to any sort of discussion on the division of space or the passage of time? (Landsberg: 1975e).

It is therefore not at all surprising to note that translating scientific material from a modern Indo-European language into a language by its nature largely outside the reach of Western science and thought, is indeed one of the most harrowing and pressing problems confronting linguists in Asia and elsewhere today. For though any scientific truth can have some sort of expression - a linguistic expression - clearly, only if in both SL and TL vocabularies similar symbolic

1. For some of the best analyses of the complex involvements of naming and address with social structure and cultural values, see Hymes, Ed., 1964: 225. 
distinctions have developed, a purely symbolic use of words can be reproduced. Otherwise, either periphrases or entirely new symbols will be required, and the degree of correspondence is at the mercy of the translator's semantic competence.

Evidently, the translator's problem begins with the fact that clearly, in any language, there is much more to meaning than what is contained in the individual word.

Looked at from a distributional viewpoint, it seems roughly that difficulties will occur on either the "static" or the "dynamic" level of language (Dagut: 1971).

On the static level, problems of "lexical anisomorphism" may arise first of all with differences in the "referential " (or denotational) meaning of single words. A look in any dual language dictionary shows immediately how this works. Thus, if we compare for instance, English people with Hawaii lāhui, we see that we need an additional English nation, race, tribe, nationality, assembly, species (Pukui and Elbert : 1973), and we can clearly see how much "finer " or narrower English "gridding" is in this case.

\begin{tabular}{|l|l|l|l|l|l|l|}
\hline \multicolumn{6}{|c|}{ lāhui } \\
\hline people & nation & race & tribe & nationality & assembly & species \\
\hline
\end{tabular}

This one-to-many lexical relationship on the referential level, is but one of the phenomena representative of semantic incongruence between two languages - an initial strumbling block for the unwary translator. However, one may draw up as it were some sort of componentional "breakdown" of the features contained in the semantic area, and compare all these data to see what lexical distinctions are to be made for each language.

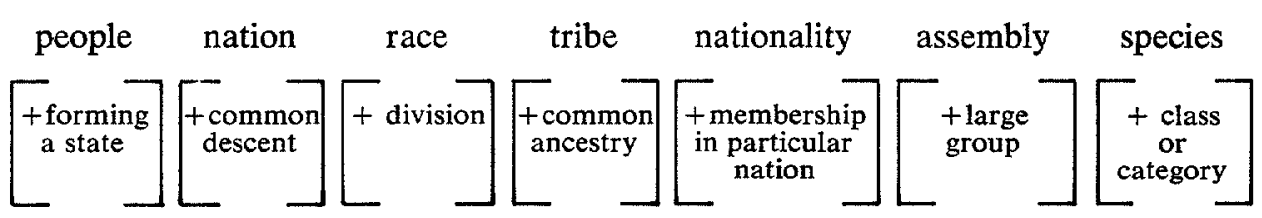

A pictorial representation of the translator's problem - and fivefold possibility of erring - would look something like below umbrella-like sketch : 


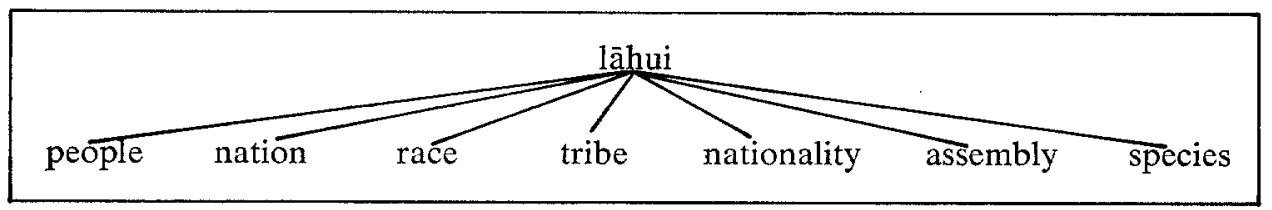

and it would ultimately be, of course, the context which defined the choice.

An even more perplexing problem in translation arises where a semantic voids" (or unknown areas of experience) occur, i.e. a situation in which lexical items in the SL simply have no designational equivalent in the TL.

In such a case the translator is not so much in danger of hitting on an entirely wrong reference, as of being put off altogether, because he cannot seem to find any fitting rendering at all...! These semantic voids occur where the lexical anisomorphism of two languages is caused by semantic discontinuities, or conceptual gaps, which may be : (a) environmental, (b) social, (c) simply lexical in content. For instance, "religious voids" would then probably belong - with "stratificational ", "professional ", and "cultural" voids - under (b): "social voids".

It may be of some interest to note here that if the only way out of this dilemma for the translator is by some sort of periphrastic means, one might be tempted to infer that the speakers of the TL apparently are not very concerned with that particular concept - or else they would "obviously " have a word for it. Thus, the full meaning of terms like Hebrew aliāh, yišūb, yorēd, can indeed only be adequately conveyed on the designational level by quite cumbersome English paraphrases, and the opposite may be true for some English words, such as repatriate.

However, one should beware of jumping to general conclusions after looking at just one pair of languages. In Hawaiian, for instance, no single term can be found for things which are clearly of the utmost importance and interest to the Hawaiians, such as magic, sex, food, the weather. To make up for this, we may find on the other hand, 64 entries for rain, and no less than 179 different potato names! (Pukui and Elbert: 1973). The number of referential synonyms, then, may very well be indicative of the complexity of attitudes towards the referent.

Under "environmental voids" are included all voids that arise from the presence in the SL (and the absence in the TL - or vice versa), of natural phenomena, climate, flora, fauna, etc. Here the translator's problem lies in the fact that the voids are "referentially based ", i.e. simply due to the absence of a certain referent from the experience of either LS or TL (e.g. snow, monsoon, etc.). However, there are mostly several, mostly periphrastic, more or less successful solutions available to choose from. 
"Social voids" occur where the lacking referents are cultural objects (ideas, situations, concepts, beliefs, practices, etc.), created from within the language community itself. Although in our age of mass media, "environmental novelties" may easily enough be incorporated into anyone's referential verbal apparatus the effective absorption of "cultural novelties" is of course much more problematic. Thus, Hebrew galūt, goy, šib'āh, tarēf, huppāh, nāhat, etc. are clearly just as baffling concepts for anyone outside the realm of Jewish culture, as for instance, Swahili kikoa "a meal eaten in common, provided by each of those who join it by turns", Arabic sūlhāh "a reconciliation feast", or Somoan tulafāle "a talkingchief ", is to anyone unacquainted with those particular cultural situations.

Especially with the interpreter ${ }^{2}$ in mind, under " social voids" we should perhaps also mention " phonological voids ", where would belong problems ranging from (a) onomatopoeia, which is registered quite differently by each society, (b) the various click-sounds carrying semantic content, such as for instance, Dutch and Polish retroflex and buccal clicks : [tlk!] - to encourage horses (or girls...!); English alveolar [tit'tst] or [t!t!] - to express disapproval or pity, Hebrew negation-clicks, or those found in some African languages, as Bushman (Stopa: 1972), to (c) various kinds of phonological sound structure modifications, such as for instance, certain types of "prestige-sound ", triggered off by social or situational cues (Landszerg: 1976b). A relevant and particularly striking example of this phenomenon is provided by the current Hebrew translation of My Fair Lady, where the "substandard "[ei] - [ai] marker or English (in : "The rain in Spain...") is replaced by a velar trill [ $\mathbf{r}]$ in Hebrew. The correspondence in status of the two kinds of markers in the two languages leaves one with something to ponder over.

Another very important class of voids that may add to the translator's worries, is the class of " lexical voids ", which seems mainly to result : (a) when commonly shared " environmental " or " cultural " data are differently categorized by different societies, different languages, like for instance, Hebrew mešeq, or (b) with certain minor parts of speech like Hebrew dawq'ā, mēlā, or harēi, German doch, Dutch hoor, French hein, Japanese ka, classical Greek ge, to mention but a few, which seem to have no English analogues at all.

"Historical voids" might perhaps as well be mentioned here, since over the ages some languages change faster than others, so that reference may have become too " slanted "for any other than etymological use. Some striking instances of this may be found in Brunner (1969). Such as are to be found there are now solely of interest and use to the comparative philologist. Another problem that may belong here is the intellectual and linguistic "coming of age " of languages. One certainly would, for instance, be very hard put when requested to translate this present paper into Bushman - no doubt an excellent linguistic vehicle for anything

2. Or inhabitants of associated intellectual realms, such as anthropoiogists, sociologists, ethnographers, etc.

See also Weisgerber : 1955 . 
of relevance to a Bushman - but with apparently as yet hardly any apparatus to handle abstract concepts (Schapera: 1965).

Another group notoriously problematic for translation is the category of " syntactic voids"- e.g. such as may originate from discrepancies in time, tense, aspect, number, modality, word sequence, choice of category, and so on. These mostly stem from the fact that languages are so often structured quite differently syntactically. Thus, some languages may have in their verb systems no time aspects (Vietnamese), no plural (Hawaiian), no continuous (Hebrew), no passive (Bushman), while yet others may lack certain impersonal forms, engendering problems as encountered, for instance, in the rendering of Hebrew yorèd gesem (agentive) $\rightarrow$ English " it rains $^{3}$ " (impersonal), only rarely (poetic) "the rains came ", which in turn cannot thus be translated into Hebrew, without either losing or adding something.

In general, the category of "syntactic voids " seems to consist chiefly of about half a dozen or so problems that in essence appear to arise from the anisomorphism of certain language-specific syntactic " markers", such as for instance :

(i) Markers for " sex" or "gender" (the latter mostly overruling the former, as in German "das Mädchen "), which may be overt or covert (Whorf : 1945). An additional translation problem may be posed by the demand for (optional or obligatory) conversion of the marker: a bound morpheme in the SL into a free morpheme in the TL - or vice versa - such as for instance, in: German "Freud-in", French " ami-e " Hebrew " ḩaber-āh " $\rightarrow$ English " girl-friend ", or, slightly more complicated, Serbo-Croat " drug-arica" (lit. "female companion") $\rightarrow$ English " girl-friend ", not to mention cases like Hebrew " dodān " (which is overtly marked for male, its female counterpart being " dodanit") $\rightarrow$ English " cousin " (which is quite unmarked out of context). And indeed, how is one to translate Turkish hardes, "brother, sister ", into Hebrew - which not only stringently differentiates between those two lexical items, but also provides the appropriate and obligatory feminine endings to its verbs ${ }^{4}$ - without being well-informed about the contextual constraints that define its gender-marker...?

It is especially in the kin-term field that such tricky traslation problems may arise. These will very often be found to stem from differing paradigmatic or syntagmatic distinctions resulting from terms being marked in one language for " age ", but in the other for "sex", as for instance in Hawaiian hele hope (lit. "younger sibling") $\rightarrow$ English " brother".

(ii) A rather interesting, unusual and somewhat related (i.e. syntactic-semantic) problem is brought into focus by Austin (1971). Thus, although some languages 3. And never English it's raining $\rightarrow$ Hebrew " magšìmīm ", or French il pleut $\rightarrow$ Hebrew

4. I.e. Hebrew ha'ah holek / ha'ahot holeket $\rightarrow$ English « the brother goes / the sister goes". 
- English, for instance - no longer have any overt morphological gender except for pronouns "he, she, it ", there still seem to be covert i.e. on the semological level (Smith : 1967), historical gender reverberations so that, according to Austin, English noums may have two genders - with appropriate markers - e.g. animate and inanimate, while adjectives and verbs may have three : e.g. animate, inanimate, and double.

Hence, the unwary translator, sooner or later, is apt to fall into any of the following three choice ambushes: (a) On the nominal level, where SL and TL deep and surface structures may clash. I am thinking here for instance, of how " naturally" the English speaker expects an active sentence employing a transitive verb to have an agentive (i.e. animate) subject. The danger is, of course, severely aggravated in the so-called "ergative" constructions, where in the English sentence the surface subject is deleted, so that what appears to be the surface subject, is in fact, the deep object of result or patient. A good example of what such a problem would look like in practice, i.e. in an English SL $\rightarrow$ Hebrew TL situation, is presented by the following pair of sentences :

1. He opened the door $\rightarrow$ hü' pātah 'et hadelet (P.Y.).

2. The door opened $\rightarrow$ hadelet nifteḥāh (Nif'al) - and not : hadelet păthāăh (P.Y.). Hebrew seems to be closer to "semantic reality".

(b) In the handling of adjectives such as " eager "- i.e. animate: "he/she is eager " - not "it is eager ", " easy " - i.e. inanimate : " the book is easy" - not " the boy is easy ", or "strong " - i.e. double: " he/she/it is strong".

(c) Dealing with verbs such as " step " - i.e. animate: " he/she steps " - not "it steps ", "elapse" - i.e. inanimate : " it elapsed " - not " he/she elapsed ", or "collapse" - i.e. double: " he/she/it collapsed".

(iii) Another purely syntactical problem may be posed by the fact that some languages have "plurality-markers", while others have not. Indeed, this may occasionally prove to be quite baffling in the translation of say, Hawaiian - which simply has no plural forms at all - into English, which has (normally marked by - s), and vice versa.

(iv) A similar problem of anisomorphism of syntactic markers in different languages would also arise for the translator attempting a direct or literal translation of a language like Hawaiian, again, which makes up for its lack of conjugations by a sort of "state-of-action-marker", as we can see for instance, from a sentence like: ua / marker-of-completed-action hele / "go "'oia / subjectmarker " he" $\rightarrow$ English " he went".

(v) Last but not least, on the static level, some quite intriguing (though not too baffling) syntactic problems of "zero representation " present themselves to the translator in the form of particles or other minor parts of speech, such as for instance, prepositions and adverbs (up, in, out), conjunctions (or, and, but), affixes (un-, in-, -ness, -ly), various courtesy markers (Landsberg: 1976b), or those SL particles that simply find no analogues in TL articles (a, an, the), as shown in below example: 
1. English : a man

2. " : the man

3. " : I saw a man

4. " : I saw $\emptyset$ the man
- Hebrew : $\emptyset$ '⿳亠ss.

- $\quad$ : haר̄s.

- $\quad$ : $\emptyset$ ra'îi $\emptyset$ 'īs.

- $\quad$ : $\emptyset$ ra'ìì̄ 'et hầs.

where we can see that in addition to the Hebrew first person singular being optional $(3,4)$ in colloquial, asterisked in correct usage - while in English it's of course obligatory in both registers - Hebrew has zero representation of the indefinite article $(1,3)$, while English has zero representation of the object-marker, in Hebrew an obligatory case marker (accusative), preceding definite article + direct object.

Though this was but a modest sample, it is obvious enough that a great deal of confusion may be caused in general, by language-specific use of certain forms, and that all sorts of perplexing problems may arise on various levels.

To sum up then, so far, we have seen that the translator's woes seem to begin with the fact that languages deal with matters of meaning each according to their own. In general, difficulties were seen to occur on roughly either the static or the dynamic level of language. On the static level we found mostly problems of "lexical anisomorphism " arising from intralingual differences or discrepancies in referential meanings. In such situations one seemed to be dealing with various kinds of "semantic voids", i.e. cases in which items in the LS simply have no designational equivalents in the TL.

Such intralingual semantic discontinuities were seen to occur mainly on three levels : (a) environmental, (b) social, and (c) lexical - to which would belong the great sub-group of syntactic voids, with its multivarious assortment of snares and traps.

However, one of the principal manifestations of interlingual anisomorphism is to be found on the dynamic level of meaning. It is clearly here that the most formidable problems will tend to arise for the conscientious translator. For apart from the problem of trying to find " equivalents " for designations which, though themselves fixed, are perhaps quite anisomorphic between SL and TL, there is the problem of changed, multiple, or "slanted " meaning to cope with in the area of figurative usage. This is the level where the meaning of an utterance is expanded semantically, bringing as it were, ever more meanings or shades of meanings under its designational umbrella.

The three large subdivisions of the figurative category are : (a) polysemy; (b) metaphor; and (c) idiom.

(i) Now, with regard to polysemy, here the translator is tossed on the horns of a real dilemma. For first of all he must distinguish between identical and non-identical SL $\rightarrow$ TL polysemic extensions of word meaning; and secondly, he must of course, in the non-identical cases find the TL " equivalent ". Only a native speaker of the TL probably has enough natural " semantic competence " to do this accurately and unerringly on all counts. 
Here would also belong certain problems of " philosophical linguistics ", best remembered by such debates as to whether the first words in "hot day ", " hot water ", " hot oven ", " hot reactor ", " hot sauce ", etc. are the "same " or not.

This argument was taken up and reformulated by Lamb (1964), who contended that the root of the problem lay on what he termed the "sememic "level. Lamb argued that since clearly, sememes and lexemes usually are not in one-to-one, but in many-to-many correspondence, it is precisely here that most problems will occur. His point was that from patterns of occurrence it would be possible to tell when a particular lexeme represented more than one sememe. As an example he cited the lexeme "big" in "big rock", "big sister", "big fool", and "big deal", which again seem to mean the "same" thing, though here with four different sememes, which can be given as "big,", "big." "big ${ }_{3}$ ", and " big $_{4}$ ", in which actually only " big $_{1}$ " and "large" (in size) could be said to belong to the same sememe (Lamb, 1964 : 57-58).

On condition it is indeed considered within the framework of its context, the advantages of the techniques of "componential analysis" (Nida: 1975) become immediately obvious here, as are indeed its intrinsic value, relevance, and indeed indispensability for translation theory.

Thus :

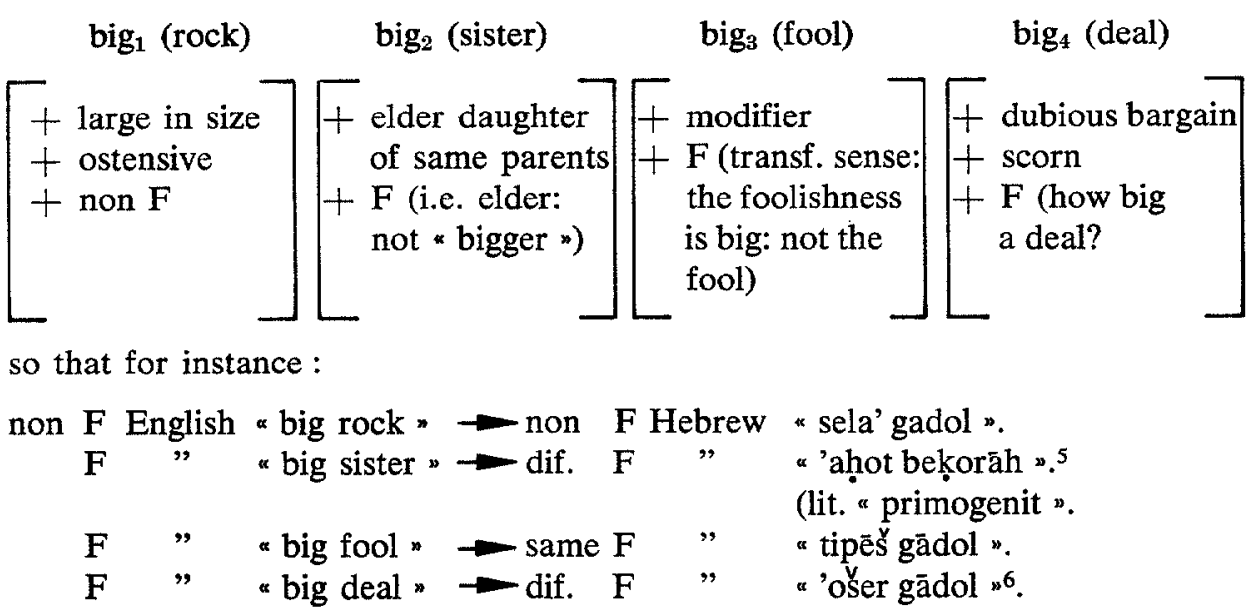

The crux of the problem is evidently that independent interlingual polysemic isomorphism (" equal-form ") happens to be extremely rare. Indeed, it is mostly at the polysemic level that machine translation tends completely to break down, for so far, machines have no semantic competence.

5. Though we hear colloq. some F : «'ahōti hagedolāh ".

6. As found in Levenston and Sivan (i968: 103) - though I myself would prefer to use: " mesiy'ah ", which to my mind better preserves (and shares with " deal ") a component of “ trade ", hence " bargain". 
(ii) The difference between polysemy and metaphor lies in the extent of the consensus about the use of the words concerned, and the expressions in their "deviant "meanings, and it is hence perhaps best to be made in terms of " simplicity" and " complexity ". For while we saw idiom as a "complex", polysemy as a "simplex" process, consisting in essence of a denotational shift (i.e. multiple meaning of a single word, such as for instance in bhed-, with basic meaning "dug-out " or " hollow", as then found in: (a) "Bedroom furniture "; (b) "The bed of the river "), moving from performance to competence, metaphor was defined as a "complex" polysemic expression, i.e. a sort of exercise in deviant performance ${ }^{7}$, creating competence, complex metaphors becoming polysemes as they enter competence.

Here the main problem for the translator lies in his having ultimately to decide on the correct (both semantically and stylistically) sort of distribution ${ }^{8}$. For translation, clearly, concerns not only languages but also source-locale $\rightarrow$ target-locale processes, involving the entire cultural structure of which the language is the vehicle. The translation model we are aiming at should therefore incorporate all data explaining how this SL-culture $\rightarrow$ TL-culture interpretation process takes place. Hence, any theory not deliberately confining itself to surface phenomena, must consider the pragmatic, i.e. social and situational aspects of its subject, and clear criteria will have to be drawn up for identifying such "appropriateness" as indicated above.

(iii) In many cases, however, the most baffling translation problems will be seen to arise from the idiomatic rather than from the metaphorical anisomorphism of SL and TL. The same "creative " or " dynamic" principle at work in polysemic linguistic change, may in turn either cause the figurative expression to disappear entirely, or (after its novelty has worn off), to take its place in the "regular" (i.e. non-figurative) vocabulary of the language as a "demetaphorized "compound. Thus, while the denotational scope of a compound metaphorical expression is greatly enlarged, when it enters everyday usage like any simplex word-symbol, its figurative force is just as significantly reduced, for once mercifully ameliorating the translator's perennial woes...

A more troublesome phenomenon from the translator's viewpoint is that many, indeed probably most languages contain idioms as startlingly vivid, picturesque - and nearly untranslatable - to us, as certain English idioms, like for instance, "paint the town red ", " have a green thumb ", "eat humble pie ", "kick the bucket ", or "be in full fig ", no doubt must appear to a speaker of say, Swahili. Indeed, to transfer such an expression into any other language, even of the same family, seems hardly feasible without in some way or another hopelessly distorting the designata. It is perhaps in general the safer, though not necessarily

7. For an outstanding discussion of the problem see Dagut (1974).

8. I.e. both co-textual (strict subcategorizational and selectional restrictions), and contextual (social and situational constraints on any utterance) features; or in other words, contextual constraints on cotext (Landsberg: 1976b). 
the most original, courageous, or " elegant "way out for the translator to decide in the majority of such cases on a sible $\mathrm{F} \rightarrow$ non $\mathrm{F}$ solution.

The least troubling of problems that may arise in the translation of SL figurative usage into TL is, I think, the category of metaphorical "loantranslation". Instances of interlingual borrowing run from the single word to whole utterances, especially complex metaphors and their idiomatic residues.

Such metaphorical "calques" are probably the only instances of figurative usage which present no SL $\rightarrow$ TL problems, since F $\rightarrow$ same F is directly available, as for instance, in English " space ship " $\rightarrow$ Hebrew " sfinat hăăăl ", though one has to rejuggle the sequence, or English "feedback * $\rightarrow$ Hebrew " hēzūn hōzēr ", where one hasn't. Neologisms like Hebrew halālīt (" spaceship "), and straight loanwords, present of course no serious problem at all, and are here only enumerated for completeness' sake.

To reflect for a moment on the above, it should be clear by now that whatever the translator suffers on the static level, is nothing compared with the distractions assailing him on the dynamic level of the SL $\rightarrow$ TL process. For here his troubles multiply like rice corns on the proverbial chessboard, and he must indeed be a master player of the translation game, to be able to move his main pieces : polysemy, metaphor, and idiom, with authority and competence.

For whoever has tried and tried again - in a storm of despair, perhaps to find " equivalents " for (probably in many cases wildly anisomorphic) interlingual designations, will no doubt shudder at the memory of that perilous experience. And yet it must be done, and so we persevere, trying to get closer to the heart of our troubles.

To sum up then, in figurative usage, SL $\rightarrow$ TL translation was generally seen represented as taking place according to one of the following four available relationships :
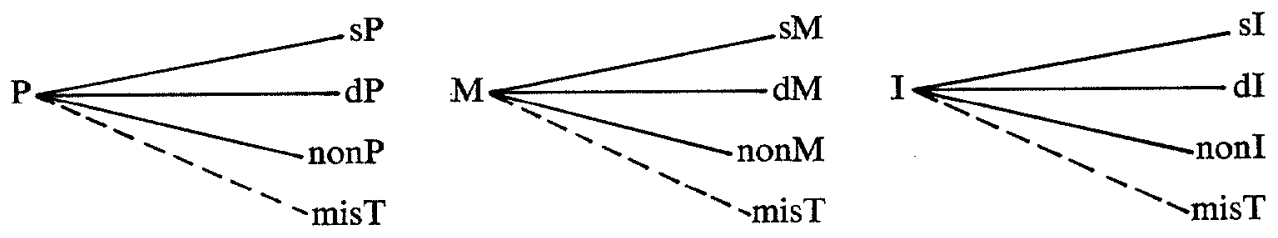

three being "possibilities ", and the fourth always lurking around the corner as a just as possible " mistranslation".

Finally, to my mind, some of the most interesting and important problems arise in connexion with the " stylistic anisomorphism " of most SL $\rightarrow$ TL situations. Contrary to most writers on the. subject, I believe that though indeed style is a matter of "choice", choice implies option, and hence indeed in matters of 
style there are no "certain certainties", still as a reflection of human behaviour, even in stylistic aspects of language most certainly distinct patterns can be detected, which in turn can be ordered into general rules (Landsberg: 1976b).

But what actually is " style "? In semantic terms, it has been most aptly described by Dagut (1971: 148), as " the social-evaluative aspect, as distinct from the denotational or connotational aspects of language.

Since evidently, social distinction of some kind or other are to be found everywhere, and languages will invariably have to reflect these in stylistic stratification, it can also be said that style is "the linguistic aspect of social stratification or situation " (Landsberg: 1976b).

It is therefore my contention that where languages differ most, stylistically, is in their reflection of the linguistic community as a social group. That is to say, in the specific values and realizations each assigns to these various strata or conditions, as reflected by the overt or covert components of context-bound or " situational "stylistic usage.

Indeed, these twin concepts of social status and social role are obviously fundamental to the realistic analysis and description of any language. For each person in society may occupy multiple statuses, is capable of projecting a thousand and one situational "identities ", and for each of these there is an all but infinite array of associated roles - non-verbal or verbal - realizing the behavioural enacting of their patterned expectations.

To relate the structure of the semantic field to the social situation in which it is used, what is required is not a semantic analysis in the formal linguistic sense, but rather an analysis of the dynamic processes of semantic fields as expressed in concrete social situations - that is to say, in normal daily face-to-face communication.

This concept of language as an action-oriented sign system shows how important it is to set up a strict differentiation between language as an "external " or purely formal sign system, and the semantic aspects of language as used in communication (i.e. the surface phenomena of our internalization of reality), and find a systematic relationship between the two. For instance, if we would wish to investigate more closely the structural implications of above-mentioned multiple roles for language, as reflected in the diverse actual motivational vocabularies, we can accumulate such information from observing these selective processes at work. However, if interlingual rapport in the communicative situation is to be brought about, it will prove necessary to detach ourselves from any single case, and search for broader generalizations. One might well ask, for instance, how it is that social identities are found represented in various cultures. We will find that this is very often brought about by an intricate technique of introducing a certain semantic hierarchy to mark the specific situational usage, such as, for instance, by way of employing a semantically marked synonym in place of the unmarked or "normal" daily variant. This procedure seems to be well enough 
known to most tongues of our globe, and its principle appears to be incorporated in our pan-human store of experience.

However, the extent and content of experience with these archetypical identities and their linguistic representations will of course vary enormously within each culture. Indeed, as Nina and Taber $(1970: 161)$ so aptly observed, the interpretation of style in translation is an "advanced exercise in the interpretation of two cultures ", i.e. in two often vastly different social, conceptual and linguistic systems, and their variables that have arisen as a result from the choices made between alternatives.

Thus, while Samoan for instance, sets up an interesting and rather complex distinction between, on the one hand, the attitude to the person addressed, the linguistic aspect of which is a system of stylistic levels, and on the other hand, the attitude to the person mentioned, the linguistic aspect of which is a trichotomic honorific system (Milner : 1961), the problem posed for the Hebrew $\rightarrow$ English translator, on the other hand, appear to be mainly " linear ", i.e. socio-historical in nature, moving as it were along a sort of style "scale" (Dagut : 1971).

In terms of general translation theory then, evidently, the assessment of style is so notoriously diverse and problematic not without good reason, and any attempt to convert one language into another, can be seen to involve infinitely more than just some rapid " mechanical "SL $\rightarrow$ TL process.

Since perception and assessment of the problems involved must of needs precede faithful transfer, a full competence in comprehending the speech of others, is to include these contextual interpretations. As we saw above, this involves a well-informed and realistic estimation of the society's stratificational and situational variables, as identifiable by their linguistic choice-markers. It has been my contention here that these constitute a system as rigidly hierarchical in nature as the social contexts that generate them, so that a formal model would be composed of the elements seen as representing the main principles of both the social and the linguistic system.

As this choice between referential equivalents in the speakers' repertoire evidently contains considerable informational or connotational content, for the aware investigator, the choice-markers of style-variations signal significant social meaning that cannot be left out of consideration.

Hence, just as we may distinguish between innate and acquired intelligence (Piaget : 1971), it appears fruitful as this stage to differentiate between linguistic social competence, the former generating all possible (i.e. gramm. correct) utterances of a language, the latter seeing to it these correct utterances are used appropriately. This second system of rules governing the specific socially learned strategies of communicative behaviour within a given society, seems to be lying over the first like a sheaf of transparencies in an overhead-projector. And it is precisely these that the "well-tuned "translator is to peel back one by one and screen off in his mind to be able to determine exactly what ingredients shall have to go into their faithful transfer. 
My dual claim (theoretical / practical) that (a) context-linked phenomena are probably identifiable in all languages of the world, whether their markers are overt or covert, and (b) that the proper identification of the problems involved may eventually lead to their resolution, and hence contribute to a better theory, seems therefore fully substantiated.

Searching for broader generalizations in terms of shared experiences and their interpretations, the basic components of which as was noticed above, may well be universal (Nida : 1975), these will have to be included in our model of language, and hence in the translation process, to relate the SL structure of the semantic field and the social situation in which it is used, to its TL equivalent. In other words, true interlingual semantic competence is seen here as the capability to creep inside the other guy's skin and think his thoughts - or at least approximately so.

Clearly then, in the long run it just isn't going to be enough simply to pronounce that an utterance is "formal " or "informal ". Indeed, the theoretician is going to have to show how exactly any added feature operates in a framework set up according to clearly and rigorously defined principles in marking the right kind of selections (i.e. "appropriate" vs. " condemned ") among alternatives.

Any sustained consideration of these problems will lead to far-reaching theoretical considerations, such as those which will have to be made within a framework of the sociology of knowledge, and prior to any consideration of transfer.

In other words, in order to predict correctly the applicability of such "realistic" rules, one must be able to refer to assumptions about the social or situational context of an utterance. Thus, once we acknowledge social markers on lexical items, rules that insert these, will have to be context-sensitive to some sort of socio-semantic features.

The justification for such a theory must surely lie in the fact that it is a process which, offering generalizations about basic processes, will ultimately lead to the elaboration of better conceptual models concerning both language and translation.

MARge E. LANDSBerg

\section{REFERENCES}

AUSTIN, William M. (1971), "Linguistics ", In : Encyclopaedia Britannica, 14: 76c Chicago.

BRUNNER, Linus (1969), Die gemeinsamen Wurzeln des semitischen und indogermanischen Wortschatzes, Versuch einer Etymologie. Bern und München: Francke.

CARROLL, John B. (Ed.) (1956), Language, thought and reality, Selected writings of Benjamin Lee Whorf. Cambridge (Mass.) : MIT.

DAGUT, M.B. (1971), A linguistic analysis of some semantic problems of Hebrew-English translation, The Hebrew University of Jerusalem, Doctoral dissertation.

DAGUT, M.B. (1974), « Metaphor as a special translation problem ", In : Ha-Sifrut / Literature, December 1974, No. 18-19; p. 120-136, Tel-Aviv University Press. 
HYMES, Dell H. (1964), Language in culture and society, A reader in linguistics and anthropology, New York, Harper and Row.

LAMB, Sydney M. (1964), "The semenic approach to structural semantics", In : Rommey, A.K. and R.G. D'Andrade (Eds.) Transcultural studies.

LANDSBERG, Marge E. (1975e), Overcoming the language bartier in science. Haifa, Manuscript.

LANDSBERG, Marge E. (1976b), The choice-markers of situation stylistics, The Hebrew University of Jerusalem, Doctoral dissertation.

LEVENSTON, Edward A. and Reuben SIVAN (1968), The Megiddo Modern Dictionary, English-Hebrew, Tel-Aviv, Megiddo.

LYONS, John (1969), Introduction to theoretical linguistics, London, Cambridge University Press.

MILNER, G.B. (1961), "The Samoan vocabulary of respect", In: Joumal of the Royal Anthr. Inst. of Gt. Britain and Ireland, 91, 2: 296-317.

NIDA, Eugene A. and Charles R. TABER (1970), The theory and practice of translation, Leiden, Brill.

NIDA, Eugene A. (1975), Componential analysis of meaning, The Hague, Mouton.

PIAGET, Jean (1971), Biology and knowledge, An essay on the relations between organic regulations and cognitive processes, Edinburgh, Edinburgh University Press.

PUKUI, Mary Kewana and Samuel H. ELBERT (1973), Hawaitan Dictionary, Honolulu, Hawaii University Press.

ROMMEY, A.K. and R.G. D'ANDRADE (Eds.) (1964), Transcultural studies.

SCHAPERA, Isaac (1965), The Khoisan peoples of South Africa, London, Routledge and Kgan Paul.

SMITH, L. (1967), "The concept of the morphophone ", In: Language, Vol. 43, No. 1, p. 306-34 I.

STOPA, Roman (1972), Structure of Bushman and its traces in Indo-European, London, Curzon.

WEISGERBER, Lea (1955), "Das Dolmetschen und die sprachliche Verwandlung del Welt", In : Babel, $1: 7-9$.

WHORF, Benjamin L. (1945), "Grammatical categories », In: Language, Vol. 21, No. 1, p. 1-11.

TRANSLATION THEORY BIBLIOGRAPHY

ALBRECHT, Jörn (1973), Linguistik und Übersetzung, Tübingen, Niemeyer.

AMOS, Flora R. (1972), Early theories of translation, New York, Octagon.

ARROWSMITH, William and Roger SHATTUCK (Eds.) (1971), The craft and contert of translation, A critical symposium, University of Texas Press.

BAUSCH, K.R. (et al.) (1970), The science of translation, An analytical bibliography, Tübingen, Spagenberg.

BELLOC, H. (1931), “On translation », In: The Bookman, New York, p. 179-185.

BIDOIS, R. LE (1960), "Le traducteur, ce méconnu », In : le Monde, 7 février, Paris.

BLOIS, J. (et al.) (1968), Problèmes de la traduction automatique, Púris, Klincksieck.

BOILLOT, F. (1949-1951), "Réflexions sur la traduction", In: French Studies, Oxford, Ill, 4 (1949), 435-350, and $\mathrm{V}, 3(1951), 253-263$.

BOILLOT, F. (1956), le Second vrai ami du traducteur, Paris, Oliven.

BONNEROT, L. (et al.) (1963), Chemins de la traduction, Domaine anglais, Paris, Didier.

BOOTH, A.D. (et al.) (1958), Aspects of translation, London, Secker and Warburg.

BOOTH, A.D. (et al.) (1967), Machine translation, Amsterdam, North-Holland Pub. Co.

BROWER, Reuben A. (Ed.) (1966), On translation, New York, Oxford University Press.

CARY, E. (1956), la Traduction dans le monde moderne, Genève, Georg. 
CARY, E. (1957), "Théories soviétiques de la traduction ", In: Babel, 3.4: 179-189.

CARY, E. (1962), "Pour une théorie de la traduction», In: Diogène, No. 40, 9b-120.

CARY, E. (1963), "L'indispensable débat ", In: Qualité en matière de traduction, Oxford, Pergamon, p. 21-48.

CARY, E. (1964), Quality in translation, Proceedings of the International Federation of Translators, Oxford, Pergamon.

CASAGRANDE, J.N. (1954), "The ends of translation", In: Eight Papers on Translation, International Journal of American Linguistics, 20-24, p. 335-340.

CATFORD, J.C. (1965), A linguistic theory of translation, An essay in applied linguistics, London, Oxford University Press.

CITROEN, I.J. (Ed.) (1967), Ten years of translation, Oxford, Pergamon.

DAGUT, M.B. (1971), A linguistic analysis of some semantic problems of Hebrew-English translation, The Hebrew University of Jerusalem, Unpublished doctoral dissertation.

DENNY, N. (1960), "Art of translation ", In: New Statesman, Nov. 26, p. 837-838.

EKVALL, Robert B. (1960), Faithful echo.

FANG, Achilles (1962), "Some reflections on the difficulty of translation ", In: Wright, Arthur F. (Ed.) Studies in Chinese thought, University of Chicago Press.

FEDOROV, A.V. (1958), * Introduction à la théorie de la traduction ", In: Izdatel'stva Literaturi na Inostrannyikh Yazihakh, Moscow.

FOSTER, M.K. (Ed.) (1958), Aspects of translation.

FRIEDRICH, Hugo (1965), Zur Frage der Übersetzungskunst, Heiderberg, Winter.

GIVÓN, Talmy (1975b), «Universal grammar, lexical structure and translatability ", In: Guenthner-Reutter, M. \& F. Guenthner (Eds.).

GRIERSON, Herbert (1949), Criticism and creation, Folcroft.

GUENTHNER-REUTTER, M. and F. GUENTHNER (Eds.) (1975), Anthology on the theory of translation, Cambridge, Cambridge University Press.

HOLMES, James E. (Ed.) (1970), The nature of translation, Essays on the theory and practice of literary translation, International Conference on Translation as an Art, Bratislawa, 1968, The Hague, Mouton.

HOUSE, Juliane (1971), Theoretical aspects of translation, University of Toronto, Unpublished MA thesis.

HUMPHRIES, B.M. (1970), "Indeterminacy of translation and theory (with a reply by W. Quine) », In: Journal of Philosophy, March 26, p. 167-178.

ITALIAANDER, Rolf (Ed.) (1965), Übersetzen, Vorträge und Beiträge vom internationalen Kongresz literarischer Ubersetzer in Hambourg, Frankfurt a.M. : Athenäum.

JUMPELT, R.W. (1961), Die Übersetzung naturwissenschaftlicher und technischer Literatur, Berlin, Langenscheidt.

KAMP, Hans (1970), On the adequacy of translations among natural and formal languages, Santa Monica (Calif.), System Development Corp.

KEEN, D. (1957), "Les mots intraduisables”, In : Vie et Langage, No. 61, p. 178-182.

KIRKWOOD, H.W. (1966), "Translation as a basis for contrastive linguistic analysis", In: International Review of Applied Linguistics, Vol. 4, p. 175-185.

KLOEPPER, Rolf (1967), Die Theorie der literaschen Übersetzung, Romanischdeutscher Sprachbereich, München, Pink.

LARBAUD, Valery (1946), Sous l'invocation de saint Jérôme, Paris, Gallimard.

LEVÝ, JiY̌i (1969), Die literarische Übersetzung, Theorie einer Kunstgattung, Frankfurt a.M., Athenäum.

LJUDSKANOV, Alexandre (1969), Traduction humaine et traduction mécanique, Paris, Dunod. 
LOCKE, William N. and A. Donald BOOTH (Eds.) (1955), Machine translation of languages, New York, The Technology Press of MIT.

LYONS, John (1969), Introduction to theoretical linguistics, London, Cambridge University Press (Esp. chaps. $10 \& 11$ ).

MALBLANC, A. (1963), Stylistique comparée du français et de l'allemand, Paris, Didier.

MOUNIN, Georges (1955), «Les belles infidèles ", In: Cahiers du Sud, Paris.

MOUNIN, Georges (1959), "La qualité en traduction », In : Babel, V, 2, p. 84-88.

MOUNIN, Georges (1964), la Machine à traduire, Histoire des problèmes linguistiques, The Hague, Mouton.

MOUNIN, Georges (1967a), les Problèmes théoriques de la traduction, Paris, Gallimard.

MOUNIN, Georges (1967b), Die Übersetzung, Geschichte, Theorie, Anwendung, München, Nymphenburger Verlagshandlung.

NIDA, Eugene A. (1964), Toward a new science of translating, Leiden, Brill and C.R. TABER.

NIDA, Eugene A. (1969), The theory and practice of translation, Adler.

POSTGATE, J.P. (1922), Translation and translations, Theory and practice, London, Bell.

PROETZ, Victor (1971), Astonishment of words, An experiment in the comparison of languages, University of Texas Press.

RABIN, Chaim (1958), "The linguistics of translation », In: Foster, M.K. (Ed.) Aspects of translation, p. 123-145.

RAFFEL, Burton (1971), The forked tongue, A study of the translation process, The Hague, Mouton.

REISZ, K. (1971), Möglichkeiten und Grenzen der Übersetzungs kritik, Kategorien und Kriterien für eine sachgerechte Beurteilung von Übersetzungen, München.

RICHARDS, I.A. (1962), “Towards a theory of translating ", In: Wright, Arthur F. (Ed.) Studies in Chinese thought, p.247-262, University of Chicago Press.

SAVORY, Theodore H. (1968), The art of translation, Boston, Writer.

SMEATON, B. Hunter (1957-1958), «Translation: its nature, problems and limitations», In: Meta, Montréal, Les Presses de l'Université de Montréal, II, 3(1957), p. 85-89; III, 4(1958), p. 9-14.

SMITH, A.H. (Ed.) (1968), Aspects of translation, London, Secker and Warburg.

SYKES, J.B. (Ed.) (1971), Technical translators' manual, Chicorel Library.

TOSH, Wayne (1965), Syntactic translation, The Hague, Mouton.

TRADUCTION AUTOMATIQUE et linguistique appliquée (1964), Choix de communications présentées à la Conférence internationale sur la traduction mécanique et l'analyse linguistique appliquée, Paris, Presses Universitaires de France.

TRANSLATION DATA 1-4 (1968-1971), Instituut voor de opleiding tot vertaler en tolk, Amsterdam.

VICKERY, B.C. (1956), "The language barrier in science", In: Linguists' Review, London, (Jan. p. 5-8; May p. 10-12).

VINAY, Jean P. (Ed.) (1952), Traductions, Mélanges offerts en mémoire de G. Panneton, Montréal, Institut de Traduction.

VINAY, Jean P. (Ed.) (1957), «Peut-on enseigner la traduction»? or: « Naissance de la stylistique comparée ", In: Meta, Montréal, II, 4, p. 141-148.

VINAY, Jean P. (Ed.) (1968), “La traduction humaine", In: le Langage; Encyclopédie de la Pléiade, Paris, Gallimard p. 729-755.

WRIGHT, Arthur F. (Ed.) (1962), Studies in Chinese thought, University of Chicago Press.

ZUBER, Roger (1968), les "Belles Infideles" et la formation du goat classique, Paris, Collin. 